\title{
THYROID GLAND HORMONES IN NEWBORN CALVES TREATED WITH CLINOPTILOLITE RECEIVING DIFFERENT AMOUNTS OF COLOSTRUM
}

STOJIĆ V, GVOZDIĆ D, ŠAMANC H, JOVANOVIĆ I and FRATRIĆ NATALIJA

\author{
Faculty of Veterinary Medicine, Belgrade
}

(Received 12. December 2004)

The aim of this study was to investigate the influence of the natural mineral adsorber clinoptilolite on serum levels of thyroid hormones in newborn calves in the first 48 hours postpartum. A total number of 68 newborn Holstein calves divided in four groups were used in the present study. Calves were randomly assigned to one of the following treatments: 1) $0.75 \mathrm{~L}$ of colostrum in $12 \mathrm{~h}$ intervals, with $5 \mathrm{~g} / \mathrm{L}$ of clinoptilolite immediately after birth (Oh), at $12 \mathrm{~h}$ and $24 \mathrm{~h}$ after birth $(0.75+)$; 2) $0.75 \mathrm{~L}$ of colostrum in $12 \mathrm{~h}$ intervals (0.75-), which represents the first control group; 3) $1.5 \mathrm{~L}$ of colostrum in $12 \mathrm{~h}$ intervals, with $5 \mathrm{~g} / \mathrm{L}$ of clinoptilolite immediately after birth (Oh), at $12 \mathrm{~h}$ and $24 \mathrm{~h}$ after birth $(1.5+)$, and 4) $1.5 \mathrm{~L}$ of colostrum in $12 \mathrm{~h}$ intervals (1.5-), which represents the second control group.

The calves were born with high blood serum thyroid hormones concentrations (9.7-13.5 nmol/L for $T_{3}$ and 201-235 nmol/L for $\left.T_{4}\right)$. At 6 . hours after birth serum thyroid hormone levels increased in all groups, but become significantly lower at 48. hours after birth. Clinoptilolite treatment could influence the rise in blood serum thyroid hormones concentration during the early postnatal period. This was most evident in the treated group of calves that received $1.5 \mathrm{~L}$ of colostrum $\left(T_{3}, 6 \mathrm{~h}\right.$, $11.7 \pm 3.4: 19.4 \pm 7.4, p<0.01 ; 1.5+v s .1 .5-)$. Results indicate that there is a possible effect of clinoptilolite treatment on blood serum thyroid hormones concentration in newborn calves during the first 48 hours of life.

Key words: Thyroxine, triiodothironine, colostrum, clinoptilolite, newborn calves.

\section{INTRODUCTION}

Thyroid gland and somatotropic axis hormones probably have a key role in the distribution of nutrients from the gastrointestinal tract to the various tissues and organs during growth. Development and growth rate of neonatal calves depend on sufficient colostrum supply, which provides high amounts of nutrients and biologically active non-nutrient substances, such as immunoglobulins, hormones, and growth factors (Campana et al., 1995). Quantifying the relationship between nutrient intake and hormone production is an important step 
needed to advance the field of hormonal regulation of growth. There is evidence that in newborn Holstein-Friesian calves the diet could significantly influence plasma thyroxine concentrations (Grongnet et al., 1985). Previous work has indicated that different amounts of ingested colostrum could have only minor effects on plasma levels of thyroid hormones (Stojić et al., 2002). At the same time, the amount of colostrum ingested during the first 32 hours of life had a strong effect on serum concentrations of IGF-I and total proteins (Kirovski et al., 2002). Clinoptilolite is a naturally occurring mineral adsorbent with a special porous crystalline structure that can be adapted for a variety of uses. It is reported that clinoptilolite can increase the rate of colostral immunoglobulin $\mathrm{G}$ resorption in newborn calves and piglets (Stojić et al., 1995; Stojić et al., 1998). We have hypothesized that clinoptilolite treatment will increase the rate of resorption of nutrients from colostrum, providing newborn animals with sufficient energy, thus lowering thyroid hormone concentrations. The aim of this work was to determine the possible influence of clinoptilolite treatment on the blood serum concentrations of thyroid hormones in newborn calves offered different amounts of colostrum during the first 48 hours of life.

\section{MATERIAL AND METHODS}

Experimental design. A total number of 68 newborn Holstein-Friesian calves was used in the present study. The calves were randomly assigned to one of the following treatments: 1) $0.75 \mathrm{~L}$ of colostrum in $12 \mathrm{~h}$ intervals, with $5 \mathrm{~g} / \mathrm{L}$ of clinoptilolite immediately after birth (0h), at $12 \mathrm{~h}$ and $24 \mathrm{~h}$ after birth $(0.75+) ; 2)$ $0.75 \mathrm{~L}$ of colostrum in $12 \mathrm{~h}$ intervals $(0.75-)$, which represents the first control group; 3 ) $1.5 \mathrm{~L}$ of colostrum in $12 \mathrm{~h}$ intervals, with $5 \mathrm{~g} / \mathrm{L}$ of clinoptilolite immediately after birth (0h), at $12 \mathrm{~h}$ and $24 \mathrm{~h}$ after birth (1.5+), and 4) $1.5 \mathrm{~L}$ of colostrum in $12 \mathrm{~h}$ intervals (1.5-), which represents the second control group. Number of serum samples analyzed for thyroid hormones is indicated in parenthesis in tables 3 . and 4.

Blood serum collection. The blood samples were obtained from the jugular vein four times: at birth (Oh), 6, 24. and 48. hours after birth. After coagulation and centrifugation the blood serum was separated and stored at $-20^{\circ} \mathrm{C}$ for subsequent analyses.

Preparation of clinoptilolite suspension. Clinoptilolite (Minazel-S, ITNMS, Belgrade, Serbia and Montenegro) suspension was prepared in accordance with the producer's instructions. The chemical composition of Minazel-S is given in table 1, as determined on ARL 94000 X-ray Spectrometer.

Table 1. Chemical composition of the mineral adsorbent (\%)

\begin{tabular}{|l|c|c|c|c|c|c|c|c|c|}
\hline Component & $\mathrm{SiO}_{2}$ & $\mathrm{Al}_{2} \mathrm{O}_{3}$ & $\mathrm{Fe}_{2} \mathrm{O}_{3}$ & $\mathrm{TiO}_{2}$ & $\mathrm{CaO}$ & $\mathrm{MgO}$ & $\mathrm{Na}_{2} \mathrm{O}$ & $\mathrm{K}_{2} \mathrm{O}$ & L.I. \\
\hline \hline Content & 66.46 & 12.77 & 2.66 & 0.12 & 3.22 & 1.11 & 0.78 & 1.21 & 9.15 \\
\hline
\end{tabular}


Acta Veterinaria (Beograd), Vol. 55. No. 1, 3-10, 2005.

Stojić $\mathrm{V}$ et al. Thyroid gland hormones in newborn calves treated with clinoptilolite receiving different amounts of colostrum

The cation exchange capacity (CAC) and type of exchanging cations were determined by the ammonium acetate method (Table 2).

Table 2. CEC and exchanging cations of the mineral adsorbent

\begin{tabular}{|c|c|c|c|c|c|}
\hline Exchanging cation & $\mathrm{Ca}^{++}$ & $\mathrm{Mg}^{++}$ & $\mathrm{Na}^{++}$ & $\mathrm{K}^{+}$ & Total \\
\hline \hline CEC mmol/100g & 121 & 25 & 25 & 2 & 173 \\
\hline
\end{tabular}

Determination of serum thyroid hormones concentrations. Blood serum thyroid hormones concentrations were determined by radioimmunoassay using commercial kits in accordance with the instructions (INEP Diagnostics, Zemun).

Statistical analysis. The results are expressed as mean values (M) and standard deviation (SD), for each group of calves. Probability and statistical significance of differences between mean values were calculated using Student's t-test.

\section{RESULTS}

Blood serum triiodothyronine $\left(T_{3}\right)$ concentrations. The results of blood serum triiodothyronine concentrations are presented in Table 3.

Table 3. Blood serum triiodothyronine $\left(\mathrm{T}_{3}\right)$ concentration (Mean $\pm \mathrm{SD} \mathrm{nmol} / \mathrm{L}$ ) in newborn calves

\begin{tabular}{|c|c|c|c|c|}
\hline \multirow{2}{*}{ Time } & \multicolumn{4}{|c|}{ Treated and control groups of calves } \\
\cline { 2 - 5 } & $0.75+$ & $0.75-$ & $1.5+$ & $1.5-$ \\
\hline \hline \multirow{2}{*}{ Oh } & $\begin{array}{c}9.7 \pm 3.9^{\mathrm{ab}} \\
\left(17^{\star}\right)\end{array}$ & $\begin{array}{c}13.2 \pm 6.2^{\mathrm{a}} \\
(15)\end{array}$ & $\begin{array}{c}10 \pm 4.2^{\mathrm{ab}} \\
(16)\end{array}$ & $\begin{array}{c}13.5 \pm 7.1^{\mathrm{b}} \\
(15)\end{array}$ \\
\hline \multirow{2}{*}{$6 \mathrm{~h}$} & $\begin{array}{c}11.4 \pm 2.4^{\mathrm{a}} \\
(17)\end{array}$ & $\begin{array}{c}12.7 \pm 5.2^{\mathrm{a}} \\
(15)\end{array}$ & $\begin{array}{c}11.7 \pm 3.4^{\mathrm{a}} \\
(16)\end{array}$ & $\begin{array}{c}19.4 \pm 7.4^{\mathrm{a}} \\
(13)\end{array}$ \\
\hline \multirow{2}{*}{$24 \mathrm{~h}$} & $\begin{array}{c}8.6 \pm 2.4^{\mathrm{b}} \\
(17)\end{array}$ & $\begin{array}{c}8.7 \pm 4.2^{\mathrm{b}} \\
(15)\end{array}$ & $\begin{array}{c}8.7 \pm 2.2^{\mathrm{b}} \\
(16)\end{array}$ & $\begin{array}{c}9.6 \pm 4.9^{\mathrm{b}} \\
(13)\end{array}$ \\
\hline \multirow{2}{*}{$48 \mathrm{~h}$} & $\begin{array}{c}6.9 \pm 1.4^{\mathrm{c}} \\
(17)\end{array}$ & $\begin{array}{c}6.1 \pm 2.2^{\mathrm{c}} \\
(15)\end{array}$ & $\begin{array}{c}6.6 \pm 1.5^{\mathrm{c}} \\
(16)\end{array}$ & $\begin{array}{c}5.4 \pm 3.0^{\mathrm{c}} \\
(12)\end{array}$ \\
\hline
\end{tabular}

Legend: *number of blood samples; ${ }^{a, b, c}$ Means in a same column not sharing a common superscript are significantly different $(p<0.05)$.

The blood serum $\mathrm{T}_{3}$ concentrations were high in newborn calves, and have increased even more $6 \mathrm{~h}$ after birth. This increase was most evident in the control group receiving $1.5 \mathrm{~L}$ of colostrums (from $13.5 \pm 7.1$ at birth to $19.4 \pm 7.4 \mathrm{nmol} / \mathrm{L}$ at 6 . hours after birth). This initial increase in the blood serum $\mathrm{T}_{3}$ concentrations was followed by a decrease to intermediate levels at $24 \mathrm{~h}$ after birth. The $\mathrm{T}_{3}$ concentrations becoming significantly lower in all experimental groups at $48 \mathrm{~h}$ after birth (5.4-6.9 $\mathrm{nmol} / \mathrm{L})$. 
Blood serum $\mathrm{T}_{3}$ concentration was significantly different at $6 \mathrm{~h}$ after birth between the control and treated groups receiving 1.5L of colostrum (Fig. 1). At $6 \mathrm{~h}$ after birth blood serum $\mathrm{T}_{3}$ concentration in the treated calves was significantly lower compared to the second control group $(11.7 \pm 3.4: 19.4 \pm 7.4 \mathrm{nmol} / \mathrm{L}$, $\mathrm{p}<0.01,1.5+$ vs. 1.5-). A similar situation was observed between the first control and the treated groups of calves that received $0.75 \mathrm{~L}$ of colostrum, although the differences between the mean $\mathrm{T}_{3}$ values at $6 \mathrm{~h}$ after birth were not significant (11.4 $\pm 2.4: 12.7 \pm 5.2, p>0.05,0.75+$ vs. $0.75-)$.

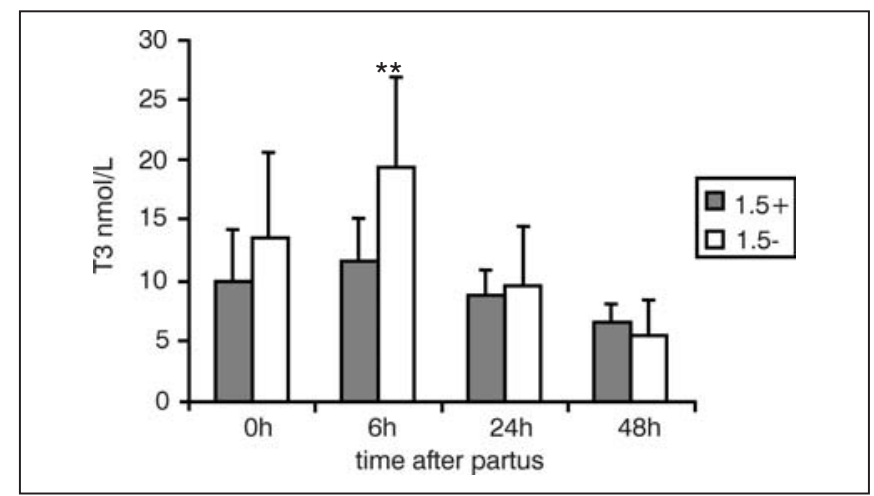

Figure 1. Blood serum $\mathrm{T}_{3}$ concentration (Mean $\pm \mathrm{SD}$ nmol) in the control (1.5-) and clinoptilolite treated $(1.5+)$ groups of calves receiving $1.5 \mathrm{~L}$ of colostrum $\left({ }^{* *} \mathrm{p}<0.01\right)$

Blood serum thyroxine $\left(T_{4}\right)$ concentrations. The results of blood serum thyroxine $\left(\mathrm{T}_{4}\right)$ concentrations are presented in Table 4.

Table 4. Blood serum thyroxine $\left(T_{4}\right)$ concentration (Mean $\pm S D$ nmol/L) in newborn calves

\begin{tabular}{|c|c|c|c|c|}
\hline \multirow{2}{*}{ Time } & \multicolumn{4}{|c|}{ Treated and control groups of calves } \\
\hline & $0.75+$ & $0.75-$ & $1.5+$ & $1.5--$ \\
\hline Oh & $\begin{array}{c}201 \pm 57^{b} \\
(13)\end{array}$ & $\begin{array}{c}209 \pm 44^{b} \\
(13)\end{array}$ & $\begin{array}{c}201 \pm 44^{b} \\
(13)\end{array}$ & $\begin{array}{c}235 \pm 100^{a b} \\
(13)\end{array}$ \\
\hline $6 \mathrm{~h}$ & $\begin{array}{c}265 \pm 59^{a} \\
(13)\end{array}$ & $\begin{array}{c}293 \pm 106^{a} \\
(13)\end{array}$ & $\begin{array}{c}264 \pm 86^{a} \\
(13)\end{array}$ & $\begin{array}{c}312 \pm 84^{a} \\
(13)\end{array}$ \\
\hline $24 \mathrm{~h}$ & $\begin{array}{c}214 \pm 44^{b} \\
(12)\end{array}$ & $\begin{array}{c}215 \pm 96^{a b} \\
(12)\end{array}$ & $\begin{array}{c}196 \pm 62^{b} \\
(12)\end{array}$ & $\begin{array}{c}223 \pm 75^{b} \\
(12)\end{array}$ \\
\hline $48 \mathrm{~h}$ & $\begin{array}{c}162 \pm 27^{c} \\
(12)\end{array}$ & $\begin{array}{c}171 \pm 56^{b} \\
(12)\end{array}$ & $\begin{array}{c}140 \pm 35^{c} \\
(12)\end{array}$ & $\begin{array}{c}144 \pm 55^{c} \\
(12)\end{array}$ \\
\hline
\end{tabular}

Legend: *number of samples; ${ }^{a, b, c}$ Means in a same column not sharing a common superscript are significantly different $(p<0.05)$. 
Mean values of blood serum $\mathrm{T}_{4}$ concentrations in all four groups of calves are given in Table 4. Our results indicate that the calves were born with high blood serum $\mathrm{T}_{4}$ concentrations (201-235 nmol/L), having an increase in the levels of $\mathrm{T}_{4}$ at $6 \mathrm{~h}$ after birth, that was more evident in the control groups of calves $(209=>293 \mathrm{nmol} / \mathrm{L}$ in $0.75-$ group, $235=>312 \mathrm{nmol} / \mathrm{L}$ in 1.5 - group of calves). This initial rise in blood serum $\mathrm{T}_{4}$ concentration was followed by a decrease at $24 \mathrm{~h}$ after birth. The mean values of $T_{4}$ in all four groups of calves becoming significantly lower at $48 \mathrm{~h}$ after birth compared to the previously observed values.

Mean blood serum $\mathrm{T}_{4}$ concentration between the control and treated groups of calves were not significantly different during all four periods of examination. However, the mean values of blood serum $\mathrm{T}_{4}$ were lower at most periods in both groups of treated calves compared to the control, especially at $6 \mathrm{~h}$ after birth in calves that received 1.5L of colostrum (Fig. 2).

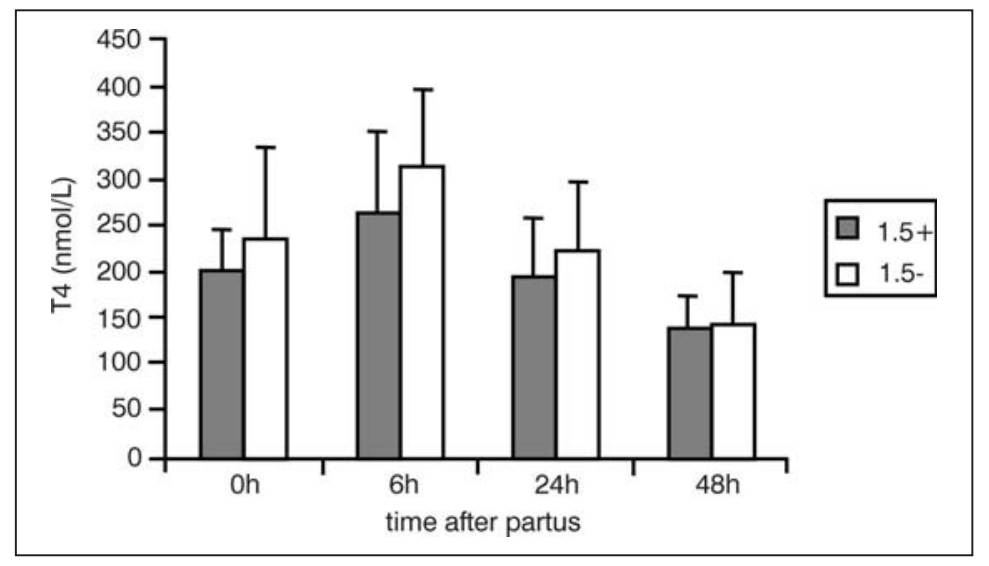

Figure 2. Blood serum $T_{4}$ concentration (Mean \pm SD nmol) in the control (1.5-) and clinoptilolite treated $(1.5+)$ groups of calves receiving $1.5 \mathrm{~L}$ of colostrum

\section{DISCUSSION}

Thyroid gland function status in newborn calves has been examined in many studies (Kahl et al. 1977; Davicco et al., 1982; Jovanović et al., 1982; Ronge et al., 1988; Hadorn et al. 1997), including our recent study concerning the intake of different amounts of colostrum (Stojić et al., 2002). These results indicate that there is a neonatal reserve of thyroid hormones that is readily available during the critical time after birth. At the same time the reducion of the amount of colostrum intake did have only minimal effects on plasma thyroid hormones concentrations (Stojić et al., 2002). Our present results confirmed the high level of blood serum thyroid hormones in newborn calves immediately after birth. Concentrations of $\mathrm{T}_{4}$ and $\mathrm{T}_{3}$ are very high at birth and decrease on day 7 after birth (Jovanović et al., 1982; Vermoreal et al., 1989; Stojić et al., 2002). Extrauterine transition of newborn 
ruminants after parturition induces a substantial rise in plasma $T_{3}$ and $T_{4}$ concentrations (Davicco et al., 1982, Polk, 1995). The thermal balance in calves during the neonatal period is supported by the well developed thermogenic mechanisms including shivering thermogenesis in muscle tissue and nonshivering thermogenesis in brown adipose tissue (BAT) (Alexander et al., 1975). Brown adipose tissue is a specialized tissue capable of generating heat by uncoupling oxidative phosphorilation from mitochondrial respiration. Thyroid hormones play an essential role in regulating BAT thermogenesis in newborn ruminants (Schermer et al., 1996). It is estimated that about $60 \%$ of plasma $T_{3}$ concentrations in newborn lambs is derived from the conversion of $T_{4}$ to $T_{3}$ by iodothyronine $5^{\prime}$-deiodinase (5'-DI) in peripheral tissues (Klein et al., 1980), and since BAT contains a high concentration of 5'-DI (Nicol et al., 1994) it could be a significant source of circulating $T_{3}$.

Results of Grongnet et al. (1985), who showed that the thyroid status is dependent on the intensity of colostrum feeding, were not entirely confirmed by our study. Thyroid hormones blood serum concentrations were not significantly different in newborn calves receiving full (1.5L) or half ration $(0.75)$ of colostrum. However, Hamon and Blum (1998) reported $\mathrm{T}_{3}$ levels that were twice as high in the group $\mathrm{M}$ (receiving milk) as in groups $\mathrm{C}_{6}$ (colostrum, 6 times) or $\mathrm{C}_{1}$ (colostrum, one time) at day 2 of age, although this difference was not significant. They concluded that the $T_{3}$ decline in plasma after birth is influenced by colostrum intake, but it is speculative and needs further investigation.

Triiodothyronine is present in cow's milk in considerably higher amounts than $\mathrm{T}_{4}$ (Ronge et al., 1988), However, the direct effect of increased milk intake on the blood plasma thyroid hormones is less probable, relating to the results of Hamon et al., (2002), who didn't find any changes in serum thyroid hormones concentrations in calves offered ad libitum vs. restricted colostrum and milk diet.

There is evidence that $T_{4}$ levels decrease during energy deficiency in newborn calves (Grongnet et al., 1985; Kinsbergen et al., 1994), but 24 hours of food restriction did not have significant effects on thyroid hormones concentration in newborn calves (Hadorn et al., 1997). Our results indicate that at 6 . hours after birth blood serum $\mathrm{T}_{3}$ concentration was significantly lower in the group of calves fed 1.5L of colostrum treated with clinoptilolite, compared to the control group of calves (Fig. 1). Furthemore, $T_{3}$ and $T_{4}$ blood serum concentration is consistently lower in the treated group of calves receiving $1.5 \mathrm{~L}$ of colostrum during all periods of the experiment (Fig. 1. and 2.). Clinoptilolite treatment seems to effectively increase intestinal resorption of biologically active substances from the colostrum in newborn calves and pigs (Stojić et al, 1995, 1998, 2003). Present results indicate the possible influence of clinoptilolite treatment on thyroid hormones blood serum concentrations in newborn calves. The effect of the mineral adsorbent clinoptilolite could be based on the increase of resorption of nutrients from the colostrum, providing the newborn calves with sufficent energy precursors, but this hypothesis needs further investigation. 
Address for correspondence

Dr Dragan Gvozdić,

Dept. of Pathophysiology,

Faculty of Veterinary Medicine,

Bul JNA 18. 11000 Belgrade,

Serbia\&Montenegro,

e-mail: gvozdic@vet.bg.ac.yu

\section{REFERENCES}

1. Alexander GA, Bennett JW, Gennell RT, 1975, Brown adipose tissue in new-born calf (Bos taurus), $J$ Physiol, 244, 223.

2. Baumrucker CR, Blum JW, 1994, Effects of dietary recombinant humal insulin-like growth factor -I on concentrations of hormones and growth factors in the blood of newborn calves, $J$ Endocrinol, 140, 15-21.

3. Campana WM, Baumrucker CR, 1995, Hormones and growth factors in bovine milk: In: RG Jensen (Ed.) Handbook of Milk Composition, Academic Press, San Diego, CA, 476-94.

4. Davicco MJ, Vigouroux E, Dardillat C, Barlet PJ, 1982, Thyroxine, triodothyronine and iodide in different breeds of newborn calves, Reprod Nutr Dev, 22, 355-62.

5. Grongnet JF, Grongnet-Pinchon E, Witowski A, 1985, Neonatal levels of plasma thyroxine in male and female calves fed a colostrum or immunoglobulin diet or fasted for first 28 hours of life, Reprod Nutr Dev, 25,3, 537-43.

6. Hadorn U, Hammon H, Bruckmaier R, Blum JW, 1997, Delaying colostrum intake by one day has important effects on metabolic traits and on gastrointestinal and metabolic hormones in neonatal calves, $J$ Nutr, 127, 2011-23.

7. Hammon MH, Blum JW, 1998, Metabolic and endocrine traits of neonatal calves are influenced by feeding colostrums for different durations or only milk replacer, J Nutr, 128, 624-32.

8. Hammon HA, Schiessler G, Nussbaum A, Blum JW, 2002, Feed intake patterns, growth performance and metabolic and endocrine traits in calves fed unlimited amounts of colostrum and milk by automate, starting in the neonatal period, J Dairy Sci, 85, 3352-62.

9. Jovanović M, Djurdjević $D j$, Stojić V, 1982, Serum thyroxine and triiodothyronine in newborn calves, Acta Vet, Beograd, 32, 73-8.

10. Kahl S, Wrenn TR, Bitman J, 1977, Plasma triiodothyronine and thyroxine in young growing calves, $\checkmark$ Endocrinol, 73,397-8.

11. Kinsbergen M, Sallmann HP, Blum JW, 1994, Metabolic, endocrine and hematological changes in 1 week old calves after milk intake, in response to fasting and during total parenteral nutrition, JVMA, 41, 268-82.

12. Kirovski D, Stojić V, Nikolić JA, 2002, Serum levels of insulin like growth factor-l and total protein in newborn calves offered different amounts of colostrum, Acta Vet Beograd, 52, 5-6, 285-98.

13. Klein AH, Oddie TH, Fisher DA, 1980, lodothyronine kinetic studies in newborn lamb, J Dev Phys, 2 , 29.

14. Nicol F, Lefranc H, Arthur JR, Trayhurn P, 1994, Characterization and postnatal development of 5'deiodinase activity in goat perirenal fat, Am J Physol, 267, R144.

15. Polk $D H, 1995$, Thyroid hormone metabolism during development, Reprod Fertil Dev, 7, 469.

16. Ronge H, Blum JW, 1988, Somatomedin $C$ and other hormones in dairy cows around parturition, in newborn calves and in milk, J Anim Physiol Anim Nutr, 60,168-76.

17. Schermer SJ, Bird JJ, Lomax MA, Shepard DAL, Symonds ME, 1996, Effect of fetal thyreoidectomy on brown adipose tissue and thermoregulation in newborn lambs, Reprod Fertil Dev, 8, 995.

18. Stojić V, Šamanc H, Fratrić N, 1995, The effect of a clinoptilolite based mineral adsorbent on colostral immunoglobulin G absorption in newborn calves, Acta Vet, Beograd, 45,2-3, 67-74.

19. Stojić V, Gagričin M, Fratrić N, Tomašević-Čanović M, Kirovski D, 1998, The effect of a clinoptilolite based mineral adsorbent on colostral immunoglobulin $\mathrm{G}$ absorption in newborn piglets, Acta Vet, Beograd, 48,1, 19-26. 
20. Stojić V, Nikolić JA, Huszenicza Gy, Šamanc H, Gvozdić D, Kirovski D, 2002, Plasma levels of triiodthyronine, thyroxine and cortisol in newborn calves, Acta Vet, Beograd, 52, 2-3, 85-96.

21. Stojić V, Gvozdić D, Nikolić JA, Šamanc H, Jovanović I, Tomašević-Čanović M, Vujanac I, 2003, The serum levels of insulin and IGF-I in newborn piglets treated with clinoptilolite, Acta Vet, Beograd, 53,4, 219-29.

22. Vermoreal M, Vernet J, Dardillat C, Demigne C, 1989, Energy metabolism and thermoregulation in the newborn calf: variations during the first day of life and differences between breeds, Can $J$ Anim Sci, 69, 103.

\title{
KONCENTRACIJA HORMONA TIREOIDNE ŽLEZDE U KRVNOM SERUMU NOVOROĐENE TELADI TRETIRANE KLINOPTILOLITOM I NAPAJANE RAZLIČITIM KOLIČINAMA KOLOSTRUMA
}

\author{
STOJIĆ V, GVOZDIĆ D, ŠAMANC H, JOVANOVIĆ I i FRATRIĆ NATALIJA
}

\section{SADRŽAJ}

Cilj ovog rada bio je da se odrede koncentracije hormona tireoidne žlezde u toku prvih 48 sati života u krvnom serumu novorođene teladi tretirane klinoptilolitom i napajane različitim količinama kolostruma. Ogled je izveden na ukupno 68 teladi, podeljene u četiri grupe: 1) grupa teladi napajanih sa $0.75 \mathrm{~L}$ kolostruma u intervalima od 12 sati i tretiranih klinoptilolitom odmah posle rođenja (0h), $12 \mathrm{~h}$ i $24 \mathrm{~h}$ $(0.75+), 2)$ prva kontrolna grupa teladi napajana sa $0.75 \mathrm{~L}$ kolostruma $u$ intervalima od 12 sati $(0.75-)$, 3) grupa teladi napajanih sa $1.5 \mathrm{~L}$ kolostruma i tretiranih klinopilolitom odmah posle rođenja (0h), 12h i 24h (1.5+), i 4) druga kontrolna grupa teladi napajanih sa $1.5 \mathrm{~L}$ kolostruma u intervalima od 12 sati (1.5-). Uzorci krvi su uzimani neposredno nakon rođenja, 6-og, 24-og i 48-og sata nakon rođenja.

Telad se rađaju sa visokom koncentracijom hormona tireoidne žlezde u krvnom serumu (0. sat, koncentracija $T_{3}: 9.7-13.5 \mathrm{nmol} / \mathrm{L}$; koncentracija $\mathrm{T}_{4}$ : 201$235 \mathrm{nmol} / \mathrm{L})$. Nakon 6 sati od rođenja koncentracije tireoidnih hormona u krvnom serumu teladi se povećava, a posle 48 sati od rođenja zapaža se statistički značajno sniženje njihove koncentracija u odnosu na sve prethodne periode ispitivanja. Tretman klinoptilolitom utiče na stepen porasta koncentracije tireoidnih hormona kod novorođene teladi u toku prvih 6 sata ispitivanja. Novorođena telad napajana sa $1.5 \mathrm{~L}$ kolostruma koja su tretirana klinoptilolitom $(11.7 \pm 3.4 \mathrm{nmol} / \mathrm{L}) 6$. sata imala su statistički značajno nižu $(p<0.01)$ koncentraciju T3 u krvnom serumu u odnosu na kontrolnu grupu životinja $(19.4 \pm 7.4 \mathrm{nmol} / \mathrm{L})$. Ovi rezultati ukazuju na moguće postojanje značajnog uticaja tretmana klinoptilolitom na promene u koncentraciji hormona tireoidne žlezde u krvnom serumu teladi u toku prvih 48 sati nakon rođenja. 